\title{
UPAYA PREVENTIF GURU KRISTEN DALAM MENGHADAPI DEGRADASI MORAL ANAK
}

\author{
Dwi Novita Sari \\ Sekolah Tinggi Teologi Sangkakala Salatiga \\ keziadwinovitasari@gmail.com
}

\begin{abstract}
The current phenomenon of child delinquency leads to moral degradation. The fact is children are no longer victims of violence, but also become perpetrators. The emergence of cases of destruction, abuse, rape and even murder carried out by children, show the weakness of moral education in Indonesia. There are two main factors that influence, namely external and internal. There needs to be synergy between parents, teachers and the community to educate children. In addition to moral education in the family and society, school becomes a parent's partner to educate and instill moral values for children in school. In this case, the teacher has a big role in shaping the child into a moral person. Especially in this case, Christian teachers (teachers who are Christian) need to have an awareness of children's needs for moral values because these values are in line with noble Christian values. This research is here to help Christian teachers by offering steps to be able to teach moral values for children in school. The author used descriptive method so that readers can see a picture of the research results more closely. The efforts to overcome children's moral degradation in school include creating a moral community, designing shared moral discipline, upholding moral discipline, teaching conflict resolution and guiding students.
\end{abstract}

Keywords: preventive efforts, Christian teachers, children's morals

\begin{abstract}
Abstrak: Fenomena kenakalan anak saat ini mengarah pada terjadinya degradasi moral. Hal ini nampak pada fakta bahwa anak bukan lagi menjadi korban namun juga menjadi pelaku. Munculnya kasus pengerusakan, aksi perundungan, pemerkosaan bahkan pembunuhan yang dilakukan oleh anak, menunjukkan masih lemahnya pendidikan moral di Indonesia. Ada 2 faktor utama yaitu internal dan eksternal yang mempengaruhi. Perlu adanya sinergi antara orang tua, guru dan masyarakat untuk mendidik anak-anak. Selain pendidikan moral dalam keluarga dan masyarakat, sekolah menjadi partner orang tua untuk mendidik dan menanamkan nilai-nilai moral bagi anak di sekolah. Dalam hal inilah guru memiliki andil besar membentuk anak menjadi pribadi yang bermoral. Khususnya dalam hal ini guru Kristen (guru yang beragama Kristen) perlu memiliki kesadaran terhadap kebutuhan anak akan nilai-nilai moral, karena nilainilai tersebut sejalan dengan nilai-nilai Kristen yang luhur. Penelitian ini hadir untuk menolong para guru Kristen dengan menawarkan langkah-langkah untuk dapat mengajarkan nilai-nilai moral bagi anak di sekolah. Penulis menggunakan metode deskriptif sehingga pembaca dapat melihat gambaran hasil penelitian secara lebih lekat. Upaya untuk mengatasi degradasi moral anak di sekolah meliputi menciptakan komunitas moral, merancang disiplin moral bersama, menegakkan disiplin moral, mengajarkan resolusi konflik dan membimbing siswa.
\end{abstract}

Kata Kunci: upaya preventif, guru Kristen, moral anak 
Pada tahun 2045 Indonesia mendapat bonus demografi yaitu $70 \%$ usia penduduk indonesia berada pada usia produktif (rentang usia 15-64 tahun). Hal ini mendorong para pendidik untuk berupaya melahirkan generasi yang cerdas, memiliki keterampilan dan berkarakter. Namun, cita-cita tersebut seakan terhambat karena fakta terjadinya banyak kasus yang melibatkan anak. Data statistik menunjukkan adanya kenaikan kasus-kasus yang melibatkan anak sebagai pelaku. Komisi Perlindungan Anak Indonesia (KPAI) mengungkapkan kasus perundungan terhadap anak-anak paling banyak didominasi oleh siswa Sekolah Dasar (SD). Diketahui, ada 25 kasus atau $67 \%$ yang tercatat oleh KPAl baik dari kasus yang disampaikan melalui pengaduan langsung maupun online sepanjang Januari sampai April 2019 (Dirhantoro, 2019).

UNICEF mendefenisikan anak sebagai penduduk yang berusia antara 0 sampai dengan 18 tahun. Senada dengan UNICEF, Undangundang Republik Indonesia No. 23 Tahun 2002 tentang Perlindungan Anak pasal 1 ayat 1 mengungkapkan bahwa anak adalah seseorang yang belum berusia 18 (delapan belas) tahun, termasuk anak yang masih dalam kandungan (UU RI, 2002). Sedangkan Undang-undang Perkawinan menetapkan batas usia 16 tahun (Huraerah, 2006). Penelitian ini akan mengambil usia anak pada rentang usia sekolah yaitu 7-17 tahun. Pada usia tersebut anak sangat rentan terhadap degradasi moral yang didapat dari pengaruh perkembangan teknologi, terutama apa yang dilihat dan didengarnya.

Sokrates, seorang filsuf Yunani memandang bahwa moral membicarakan masalah bagaimana seharusnya kita hidup (Rachels, 2003). 
Dengan demikian dapatlah dipahami bahwa fungsi moral adalah mengatur perilaku individu. Menurut Lickona, pendidikan moral perlu dilakukan di sekolah untuk membentuk moral yang baik. Rasa hormat, tanggungjawab, kejujuran dan nilai-nilai lainnya memberikan muatan moral yang dapat dan harus diajarkan oleh sekolah dalam suatu demokrasi pendidikan (Lickona, 2014). Dalam hal ini sekolah memerlukan lebih dari sekadar daftar nilai. Sekolah memerlukan suatu konsep karakter dan komitmen untuk mengembangkan konsep tersebut dalam diri para siswanya.

Lawrence Kohlberg memaparkan bahwa perkembangan moral seorang anak erat hubungannya dengan cara berpikir seorang anak. Bagaimana seorang anak memiliki kemampuan untuk melihat, mengamati, memperkirakan, berpikir, menduga, mempertimbangkan dan menilai akan mempengaruhi perkembangan moral dalam diri anak (Kohlberg, 1995). Namun hal ini tidak menjamin bahwa seorang anak yang cerdas akan memiliki perkembangan moral yang baik.

Beberapa kasus menunjukkan rentannya degradasi moral yang melibatkan anak sebagai pelaku. Beberapa diantaranya, kasus meninggalnya Hilarius Christian Event Raharjo siwa kelas X di SMA Budi Mulya di Bogor akibat dipaksa duel oleh seniornya yang terbongkar 15 September 2017 silam (Palupi, 2017). Tindakan sodomi yang dilakukan oleh siswa kelas 6 SD (GD) di Wonogiri terhadap 25 temannya (Haryanto, 2017), terkuak pada tanggal 5 April 2017 lalu, sempat menggemparkan daerah Wonogiri. Kasus perundungan di Kalimantan yang dilakukan oleh 12 pelajar terhadap Audrey (siswi SMP) hingga 
melukai fisik bahkan alat kelamin juga menambah daftar panjang fenomena degradasi moral yang semakin berkembang (Fadhil, 2019).

Pada akhirnya dunia pendidikan disebut-sebut memberikan andil dalam terjadinya banyak kasus. Peran guru paling banyak diberikan sorotan dalam hal pengawasan dan usaha mendidik moral anak. Terlebih guru dengan "label" Kristen, memiliki tanggungjawab besar terhadap moral anak untuk mengarahkannya sesuai nilai-nilai Kristen. Penanaman nilai-nilai moral dirasa sangat penting dan vital bagi perkembangan kehidupan anak. Oleh sebab itu, penelitian ini akan memberikan pemaparan beberapa upaya yang dapat dilakukan oleh guru Kristen untuk dapat mengantisipasi terjadinya degradasi moral anak di sekolah.

\section{METODE}

Untuk dapat menggambarkan secara lebih dekat fenomena diatas peneliti menggunakan metode deskriptif. Metode deskriptif merupakan suatu cara untuk menggambarkan objek atau masalah yang diteliti. Metode ini dimaksudkan untuk memahami fenomena tentang apa yang dialami oleh subyek penelitian misalnya perilaku, persepsi, motivasi, tindakan dan lain-lain secara holistik dengan cara dekripsi (Moleong, 2010). Pemilihan metode deskriptif dalam penelitian ini dianggap lebih tepat untuk menyajikan fenomena yang realistis bagi pembaca. Metode ini berusaha mengungkapkan objek penelitian dengan penggambaran yang jelas sehingga pembaca dapat mendekati pemahaman seperti yang peneliti hendak ungkapkan dan hal ini cocok untuk menjawab permasalahan dalam penelitian ini. 
Prosedur pengumpulan data dilakukan dengan pengumpulan data literatur dan penelitian-penelitian sejenis. Prosedur penelitian dilakukan dengan pengumpulan data, kemudian dilanjutkan dengan menganalisis fenomena dengan data yang ada dan terakhir penarikan kesimpulan. Teknik analisis yang dipakai adalah analisis deskriptif. Analisis Deskriptif adalah cara penganalisisan dengan mengupas masalah yang ada yaitu menganalisis masalah atau fenomena yang muncul, indikator masalah dan penyelesaianya kemudian menyajikanya dalam bentuk deskriptif. Dengan demikian diharapkan penelitian yang dihasilkan dapat dipahami secara lekat lewat gambaran-gambaran yang telah disajikan dalam penjabaran data dan hasil analisis.

\section{HASIL}

Upaya preventif yang dapat dilakukan guru Kristen adalah mengajarkan nilai-nilai moral di kelas dengan cara sebagai berikut:

\section{Menciptakan Komunitas Moral Kelas}

Anak-anak bertumbuh dan bergaul dengan teman-teman seusianya. Guru tidak dapat menanamkan nilai-nilai tanpa melibatkan teman-teman sepergaulan mereka. Membentuk komunitas moral di kelas merupakan langkah awal yang dapat dilakukan untuk mengupayakan mengurangi perilaku menyimpang di sekolah. Dalam hal ini guru membantu siswa saling mengenal, menghormati dan peduli, serta menjadikan siswa merasa sebagai anggota yang dihargai dalam kelompok atau kelasnya. 


\section{Merancang Disiplin Moral Kelas}

Pendekatan yang digunakan di kelas adalah menggunakan kedisiplinan sebagai sarana untuk mengajarkan nilai-nilai seperti sikap hormat dan tanggungjawab. Disiplin diri merupakan suatu bentuk kontrol diri sebagai dasar kepatuhan terhadap peraturan dan hukum yang adil. Disiplin dalam kelas dirancang secara bersama-sama dengan siswa agar dapat dipatuhi sebagai bentuk konsekuensi yang mereka buat sendiri. Siswa akan cenderung mentaati karena bentuk disiplin tersebut, mereka buat untuk mereka patuhi sebagai bentuk tanggungjawabnya.

\section{Menegakkan Disiplin Moral Kelas}

Prinsip utama disiplin moral dalam pembuatan konsekuensi adalah menetapkannya sebagai sebuah peluang untuk memberikan pendidikan moral. Guru menciptakan dan menegakkan peraturan untuk menjadikan peraturan tersebut sebagai sebuah kesempatan guna menumbuhkan penalaran moral, kontrol diri dan sikap hormat yang sama terhadap siapa saja. Apabila ada pelanggaran yang dilakukan setelah peraturan dibuat, maka harus diberikan konsekuensi pada yang melanggar. Hal ini harus dilakukan secara konsekuen agar siswa menanggapi peraturan tersebut serius.

\section{Mengajarkan Resolusi Konflik}

Resolusi konflik perlu diajarkan agar siswa memiliki kapasitas dan komitmen untuk menyelesaikan konflik secara adil dan dengan cara-cara non kekerasan. Hal ini tentu membutuhkan pendampingan guru dari waktu ke waktu. 


\section{Membimbing Siswa}

Cara mengajarkan sikap menghormati dan tanggungjawab di kelas melibatkan guru untuk berperan aktif membimbing siswa. Dalam membimbing siswa guru harus mampu memperlakukan siswa dengan perasaan cinta dan hormat. Hal ini dapat dilakukan dengan memberikan contoh-contoh yang baik, mendukung perilaku pro sosial dan mengoreksi tindakan-tindakan yang keliru. Guru perlu membimbing siswa dalam setiap fase kesulitannya, baik kesulitan akademis maupun sosial di sekolah.

\section{PEMBAHASAN}

\section{Bentuk-bentuk Degradasi Moral}

Moral mencakup kondisi pikiran, perasaan, perkataan dan perbuatan atau perilaku. Bentuk-bentuk degradasi moral dapat dilihat dari keempat unsur diatas, yaitu:

\section{Pikiran}

Pikiran adalah hasil berpikir (memikirkan); akal; ingatan; akal (dalam arti daya upaya); angan-angan; gagasan: pikiran baru; niat (KBBI, 2016). Berpikir memungkinkan seseorang untuk merepresentasikan dunia sebagai model dan memberikan perlakuan terhadapnya secara efektif sesuai dengan tujuan, rencana, dan keinginan (Riska, 2012). Pola pikir memang tidak dapat dilihat secara kasat mata. Namun, pola pikir dapat dinilai dari tindakan keseharian yang dilakukan dan perkataan yang paling sering diucapkan untuk menilai sesuatu. 
Pola pikir anak terbentuk dari kebiasaan dan nilai-nilai yang ditanamkan oleh orang-orang disekitarnya. Pola pikir negatif dapat terjadi lewat apa yang "dikonsumsinya" sehari-hari yaitu apa yang dilihat dan didengarnya setiap hari. Bentuk degradasi moral dalam pikiran yang dilakukan anak adalah adanya pikiran negatif hendak memukul atau melakukan perundungan pada temannya.

\section{Perasaan}

Perasaan adalah respon yang dipelajari tentang sebuah keadaan emosi di lingkungan atau kebudayaan tertentu (Riska, 2012). Perasaan mempengaruhi pikiran dan perilaku dalam diri individu. Perilaku yang baik dapat tercipta jika individu mampu menyelaraskan pikiran dengan perasaan yang positif. Bentuk degradasi moral dalam hal ini adalah keinginan untuk mencaci orang lain, tidak memiliki empati, kebencian yang mendalam dan rencana balas dendam.

\section{Perkataan}

Kata-kata kasar adalah umpatan yang diucapkan. Kata-kata kasar bagi sebagian anak secara tidak sadar mudah terlontar. Hal ini karena tingkat keseringan mengucapkan yang dilakukan oleh anak. Kata-kata kasar dalam etika kehidupan tidak pernah diperkenankan dilakukan. Oleh sebab itu, hal ini menjadi bentuk degradasi moral yang perlu diperangi. Bentuk degradasi moral dalam hal ini berupa kata-kata umpatan, kata-kata kasar atau tidak senonoh, dan aksi saling mengejek yang dilakukan oleh anak. 


\section{Perilaku}

Perilaku adalah kehendak yang muncul lewat perbuatan. Beberapa bentuk degradasi moral dalam perilaku adalah tindak pemukulan, tindakan anarkis, tawuran, pengeroyokan, persekusi, tindak asusila berupa menonton video porno, melakukan hal-hal seronok seperti memegang bagian tubuh (alat vital atau bagian tubuh sensitif lainnya) dari teman yang berlainan jenis, tindak pemerkosaan dan lain sebagainya. Perilaku negatif yang muncul merupakan akumulasi dari degradasi moral dalam pikiran, perasaan dan seringkali juga perkataan.

\section{Faktor Penyebab Degradasi Moral}

Beberapa hal pemicu munculnya degradasi moral ada 2 yaitu faktor internal dan faktor eksternal.

\section{Faktor internal}

\section{Keinginan yang tidak kesampaian}

Anak-anak memiliki keinginan yang sangat besar. Mereka mudah tertarik dengan sesuatu yang mereka lihat, seperti mainan, pakaian, makanan dan lain sebagainya. Keinginan tersebut akan bertambah besar seiring pengetahuannya yang bertambah banyak (Prasetyo \& Listyandari, 2014). Dalam hal ini orang tua tidak boleh terus menerus memberikan apa yang diinginkan karena akan membentuk anak menjadi manja dan sulit dikendalikan. Pengendalian yang dilakukan oleh orang tua lewat larangan yang diberikan seringkali menyebabkan anak marah, kecewa dan menangis. Berikutnya anak akan melakukan tindakan yang 
sedikit "anarkis" supaya keinginannya dapat dipenuhi.

\section{Energi yang tidak tersalurkan}

Dunia anak adalah dunia bermain. Pada usia mereka, anak membutuhkan asupan makanan yang tinggi dan bergizi. Selain berguna untuk pertumbuhan fisik anak, asupan makanan yang cukup juga menghasilkan energi yang besar pada anak. Energi ini harus disalurkan lewat kegiatan fisik agar badan dan otak anak bekerja secara normal. Pengekangan anak dari aktivitas yang diinginkannya akan membuat energinya tidak tersalurkan. Akibatnya anak susah tidur, rewel dan berperilaku aktif. Bila dikekang terus menerus maka anak mulai menunjukkan pemberontakannya lewat sikap acuh, marah, dan tindakan agresif lainnya (Prasetyo \& Listyandari, 2014).

\section{Kebutuhan akan penerimaan}

Setiap orang butuh diterima oleh orang lain. Hal ini merupakan kebutuhan dasar manusia yang tidak dapat tergantikan. Apabila kebutuhan ini kurang terpenuhi maka akan muncul tindakan-tindakan untuk mendapat pengakuan keberadaan seseorang sebagai individu (menunjukkan eksistensinya) (Prasetyo \& Listyandari, 2014). Demikian juga dalam diri anak-anak. Jiwa anak-anak yang masih labil, seringkali mendorong anak berperilaku tertentu supaya diperhatikan orang lain. Hal ini sebagai bentuk eksistensi dirinya sehingga anak tersebut mendapat pujian, disayangi, diperhatikan dan disukai oleh orang lain maupun lingkungan. 


\section{Faktor eksternal}

\section{Lingkungan}

Lingkungan dimana anak dilahirkan, tinggal dan tumbuh memiliki pengaruh yang sangat besar terhadap perilaku anak. Ada 3 lingkup lingkungan tempat anak tumbuh dan berkembang meliputi lingkungan keluarga, lingkungan sekolah dan lingkungan masyarakat. Lingkungan keluarga merupakan tempat terdekat yang bersinggungan dengan anak dan faktor terkuat munculnya perilaku tertentu pada anak. Pola asuh yang salah dalam keluarga dapat membentuk anak kehilangan moralitasnya. Beberapa jenis pola asuh yang salah adalah permisif dan otoriter.

Pola asuh permisif yaitu memanjakan anak dengan menuruti semua keinginanya membentuk anak tidak survive dalam menghadapi realitas sosial yang ada. Anak juga mudah mengacam orang tua apabila keinginannya tidak terpenuhi. Sedangkan pola asuh otoriter menerapkan hukuman secara luar biasa apabila anak tidak melanggar atau tidak menuruti aturan orang tua. Pola asuh ini membentuk kedisiplinan anak dengan baik namun disisi lain anak akan tumbuh tanpa inisiatif sehingga sulit mengambil keputusan secara mandiri.

Di lingkungan sekolah masih didapati sikap feodal anak-anak. Sikap feodal adalah sikap menjajah. Di dalamnya dikenal adanya istilah senior dan yunior. Kaum senior dianggap lebih berwenang dalam berbagai hal dibandingkan dengan yang yunior. Sikap feodal yang berkembang di sekolah dapat mengakibatkan adik kelas (siswa baru) 
mengalami diskriminasi dari kakak tingkat. Sikap yang demikian membuat anak menjadi semena-mena dalam memperlakukan orang lain karena merasa diri hebat dan lebih kuat. Beberapa perilaku yang muncul cenderung merusak dan bersifat kriminal.

Di lingkungan masyarakat saat ini muncul juga budaya permisif. Budaya permisif mengijinkan semua budaya yang baik maupun buruk masuk secara bebas ke lingkungan masyarakat. Apabila hal ini diadopsi oleh keluarga tanpa mempertimbangkan efek jangka panjang yang diakibatkan maka dikhawatirkan anak tumbuh menjadi generasi yang brutal. Selain itu budaya ini juga dapat merusak budaya lokal masyarakat.

\section{Dampak negatif teknologi}

Tidak dapat dipungkiri bahwa teknologi memberi kemudahan dan manfaat yang luarbiasa bagi manusia. Namun disisi lain penggunaan yang kurang tepat mengakibatkan dampak negatif yang besar bagi anak. Akses teknologi dapat diterima oleh anak lewat:

\section{Gadget}

Anak yang belum matang secara moral dan diberi kebebasan mengakses seluruh kemudahan teknologi yang ada di dalam gadget lebih rentan mengalami degradasi moral dibandingkan dengan anak pada jaman dahulu. Anak membutuhkan filter tentang apa yang boleh diakses oleh anak seusianya dan apa yang tidak boleh diakses dengan penjelasan yang dapat dipahami dan diterima oleh mereka. 
Televisi

Tayangan iklan, sinetron maupun film yang banyak beredar di televisi ikut andil dalam mendidik anak. Keinginan anak menonton televisi sebagai hiburan setelah pulang sekolah seharusnya menjadi hal yang baik. Namun tayangan yang berbau pornografi selalu muncul dengan bebas ditengah tontonan yang ada. Misalnya iklan obat pelangsing, iklan alat kontrasepsi, cara berpakaian para artis yang sangat "terbuka", filmfilm luar negeri, sinetron yang menayangkan adanya genk anak sekolah, adegan percintaan dan perkelahian, menambah semakin menurunnya kesadaran anak akan moral karena keinginan meniru yang tinggi.

\section{Pandangan Teologis Pendidikan Moral}

Kekristenan memandang bahwa pendidikan moral sangat penting dan perlu diajarkan sejak usia anak-anak. Hal itu nampak dalam keseluruhan Alkitab yaitu Perjanjian Lama yang mengajarkan bagaimana hidup benar dan Perjanjian Baru yang mengajarkan bagaimana harus hidup sebagai orang Kristen yang tinggal dalam anugerah Tuhan. Tulisan rasul Paulus dalam 2 Timotius 2:15, 22-25, secara implisit menyatakan bahwa pengajaran yang buruk mengantarkan pada moral yang buruk dan pengajaran yang baik mengantar pada moral yang baik (Bergant \& Karris, 2002).

Kekristenan memiliki nilai lebih dibandingkan dengan kepercayaan lain. Dalam kekristenan semua perbuatan baik yang dilakukan adalah karena ucapan syukur terhadap anugerah yang diberikan oleh Tuhan lewat karya penebusan-Nya. Karena itu Matius 5:13-16, mengungkapkan 
bahwa sebagai orang Kristen harus mampu menjadi garam dan terang dunia. Hal tersebut dapat terjadi ketika sikap dan perbuatan yang nampak, dilandasi dari hati dan pikiran yang bermoral. Dalam hal ini tonggak penanaman nilai berada ditangan guru. Guru harus peka dan menyadari bahwa kumpulan pengetahuan dan pengalaman bukanlah satu-satunya ramuan untuk mengasuh anak-anak dan menjadikan sikap mereka baik (Cully, 1995). Oleh sebab itu, guru Kristen perlu melihat pendidikan moral sebagai tanggungjawab yang penting.

\section{Upaya Preventif Guru Kristen}

Upaya preventif berfungsi sebagai filter untuk menangkal pengaruh tren saat ini yang cenderung bersifat menjuruskan perilaku siswa terhadap tindakan yang tidak sesuai dengan aturan yang ada di sekolah. Misalkan, akses internet bebas untuk membuka video dan sosial media di sekolah, gaya berpakaian yang tidak sesuai dengan peraturan sekolah, perilaku yang mengikuti tuntutan tren seperti membentuk geng dan lain sebagainya. Hal tersebut tentu akan memunculkan hal-hal yang dikhawatirkan merusak pikiran, perasaan, perkataan dan perilaku siswa menjadi kurang baik. Upaya preventif yang dapat dilakukan guru adalah dengan mengajarkan nilai-nilai moral di kelas dengan cara sebagai berikut:

\section{Menciptakan komunitas moral kelas}

Membangun hubungan yang dekat dengan siswa akan menolong guru dalam mengajarkan nilai-nilai secara lebih dekat. Hal ini dapat dilakukan dengan membangun komunitas moral di kelas. Pelatihan moral 
yang paling baik dan paling dalam diperoleh melalui interaksi sosial dengan orang lain. Namun sistem pendidikan yang mengabaikan hal ini akan menghancurkan atau membuat nilai moral sulit untuk diajarkan (Archambault, 2013). Senada dengan hal tersebut, John Dewey dalam bukunya The Need for a Philosophy of Education mengatakan bahwa pendidikan gagal jika tidak menganggap sekolah sebagai salah satu bentuk kehidupan masyarakat (Lickona, 2014). Untuk dapat berhasil dalam mengajarkan sikap hormat dan bertanggungjawab, guru harus menjadikan upaya pembentukan komunitas moral kelas sebagai tujuan pendidikan utama.

Siswa belajar tentang moralitas dengan cara mempraktikkannya di kelas. Mereka harus berada di dalam sebuah komunitas. Siswa harus berinteraksi, menjalin hubungan, menyelesaikan masalah, berkembang sebagai sebuah kelompok, dan belajar langsung. Siswa belajar langsung dari pengalaman sosial yang mereka rasakan sendiri pelajaran-pelajaran tentang bermain adil, kerjasama, memaafkan, dan menghormati harkat dan martabat setiap individual. Kebutuhan akan interaksi sosial semacam ini di sekolah semakin besar. Ada tiga kondisi dasar yang membentuk komunitas moral di kelas, yaitu: Pertama, siswa saling mengenal satu sama lain. Kedua, Siswa menghormati, mendukung, dan peduli terhadap satu sama lain. Ketiga, siswa diterima sebagai anggota kelas dan bertanggungjawab terhadap kelompok. Guru dapat menggunakan metode kooperatif untuk memunculkan interaksi sosial dan kerjasama diantara siswa. 


\section{Merancang disiplin moral kelas}

Disiplin moral adalah penggunaan disiplin sebagai sarana pengembangan moral. Emile Durkheim mengungkapkan bahwa disiplin bukanlah suatu alat sederhana yang bisa digunakan untuk menciptakan kedamaian semu di dalam kelas; disiplin adalah moralitas kelas sebagai sebuah masyarakat kecil (Durkheim, 1973). Pendekatan ini berdasar atas tujuan utama kedisiplinan, yaitu disiplin diri. Hormat dan tanggungjawab merupakan bentuk kematangan karakter yang diharapkan oleh masyarakat. Disiplin tanpa pendidikan moral akan sama artinya dengan sekedar mengontrol kerumunan dan mengelola perilaku tanpa mengajarkan moralitas.

Disiplin moral memiliki tujuan jangka panjang untuk membantu anak-anak dan remaja berperilaku secara bertanggungjawab, dalam setiap situasi, bukan hanya ketika ada orang dewasa yang mengawasi. Ada empat hal yang dilakukan oleh guru-guru yang mempraktekkan disiplin moral, yaitu: Pertama, guru memproyeksikan pengertian kewenangan moral secara jelas dan tegas. Hak dan kewajiban guru untuk mengajarkan nilai-nilai moral seperti hormat dan tanggungjawab dan membuat para siswa bertanggungjawab terhadap standart perilaku tersebut. Kedua, guru memandang kedisiplinan, termasuk persoalan pembuatan peraturan, sebagai bagian yang penting dan harus dipatuhi bersama. Ketiga, guru membangun dan menegakkan konsekuensi dengan cara yang mendidik, yaitu cara yang membuat siswa menghargai tujuan peraturan, bersedia mengubah perilaku yang salah dan merasa 
bertanggungjawab memperbaiki perilaku. Keempat, guru menunjukkan sikap peduli dan hormat pada siswa dengan mencoba menemukan penyebab timbulnya persoalan kedisiplinan dan solusi yang dapat membantu keberhasilan siswa bersangkutan dan menjadi komunitas kelas yang bertanggungjawab (Lickona, 2014).

Cara pertama melibatkan siswa agar bersedia berbagi tanggungjawab dalam menciptakan disiplin kelas adalah membuat peraturan secara bersama-sama. Peraturan yang didasarkan pada rasa hormat menghormati dan kerjasama akan berakar dalam benak anakanak (Piaget, 1989). Jika guru dan siswa merumuskan peraturan bersama-sama, peraturan tersebut akan menjadi sebuah bentuk kerjasama dan saling menghormati dalam mengembangkan komunitas moral. Ada dua keuntungan dari peraturan yang dirumuskan bersamasama dengan siswa, yaitu: Pertama, siswa dapat mengenal setiap anggota komunitas karena dalam merancang peraturan bersama memadukan pembuatan peraturan dan pembangunan komunitas. Kedua, membuat peraturan bersama-sama melibatkan siswa dalam mendiskusikan dan memikirkan peraturan kelas. Hal ini melatih tanggungjawab siswa.

Guru dapat melakukannya dengan membagi siswa dalam beberapa kelompok dan secara bersama-sama menyusun sebuah daftar peraturan yang dibutuhkan kelas. Inti dari peraturan tersebut adalah mengusahakan kelas menjadi tempat yang aman, nyaman dan menyenangkan untuk belajar. Setelah itu usulan peraturan dari tiap kelompok dipilih berdasarkan kesepakatan bersama dengan guru. Meli- 
batkan siswa dalam membuat peraturan kelas dan mengajar siswa untuk bertanggungjawab terhadap peraturan tersebut secara pribadi maupun kelompok, memberikan beberapa manfaat yaitu mewujudkan terbentuknya kemitraan dalam kelas, mendorong tumbuhnya rasa memiliki peraturan kelas dan kewajiban moral untuk mematuhi peraturan tersebut pada diri siswa, memperlakukan siswa sebagai pemikir moral dan membantu membangun penalaran moral yang lebih baik, membantu siswa belajar berpikir kritis dalam melihat peraturan dan membangun kompetensi untuk membuat peraturan yang baik, serta menekan kontrol internal bukan eksternal sehingga mendorong timbulnya kepatuhan terhadap peraturan dan hukum (Lickona, 2014).

\section{Menegakkan disiplin moral kelas}

Untuk menjadikan disiplin moral sebagai prinsip utama dalam pembuatan konsekuensi sehingga dapat digunakan sebagai peluang untuk memberikan pendidikan moral, maka diperlukan beberapa hal:

\section{Melaksanakan peraturan sebagai momen pengajaran}

Akan lebih tepat bagi guru apabila menegur dengan mendekati anak yang melanggar dan menanyakan alasan anak tersebut, dari pada hanya memberikan peringatan di depan kelas. Hal ini juga akan membangun hubungan baik dan penuh kasih sayang antara guru dengan murid. Selain itu, murid akan lebih respect terhadap guru dan pengajarannya. 


\section{Melibatkan siswa dalam merumuskan konsekuensi}

Dengan mendiskusikan konsekuensi yang adil dan efektif, guru dapat membantu siswa memahami bahwa tujuan dari sebuah konsekuensi bukan untuk membuat siswa yang melanggar menderita, tetapi membantu memperbaiki perilaku.

\section{Tanggungjawab bersama untuk menciptakan kelas yang teratur}

Semua pendekatan yang dilakukan oleh guru untuk mengupayakan semangat tanggungjawab anak tidak dapat dilihat secara instan. Oleh sebab itu perlu dilakukan secara terus menerus dan teratur.

\section{Mengajarkan resolusi konflik}

Dalam kegiatan belajar dan bersosialisasi anak-anak di sekolah, akan muncul gesekan karena perbedaan individu. Tidak jarang hal ini akan memunculkan banyak konflik atau masalah. Oleh sebab itu anakanak perlu dibekali resolusi konflik yang baik. Guru perlu mengajarkan dan membimbing bagaimana anak-anak harus menyikapi suatu masalah tanpa kekerasan dan dapat menemukan solusi bagi masalahnya sendiri.

\section{Membimbing siswa}

Dalam kondisi sosial saat ini yang semakin memburuk, sekolahsekolah yang memiliki harapan dalam hal pembangunan karakter harus berusaha membuat siswanya untuk "melek moral". Guru perlu memiliki hubungan yang baik dengan siswanya dikelas agar setiap pengajaran dan arahan dapat diterima oleh siswa. Memiliki hubungan yang baik dengan kelas berarti memiliki hubungan personal yang hangat, saling 
menyayangi dan selaras dengan para siswa. Hal ini membuat siswa nyaman sehingga lebih mudah untuk membicarakan berbagai masalah serta reseptif terhadap bimbingan moral yang diberikan. Tanpa hubungan yang baik, pengaruh moral seorang guru akan banyak berkurang. Selain itu riset menunjukkan bahwa hubungan yang hangat dan penuh dukungan antara anak-anak dan orang dewasa sangat penting dalam membangun rasa peduli anak terhadap orang lain (Rahts, M, \& Simon, 1987).

\section{KESIMPULAN}

Perubahan kenakalan anak saat ini yang mengarah pada fenomena degradasi moral, perlu mendapat perhatian serius dari berbagai pihak. Terpaan berbagai faktor pendorong terjadinya degradasi moral baik dari internal maupun eksternal perlu diwaspadai. Bentukbentuk degradasi moral terlihat dari pikiran, perasaan, perkataan, dan perilaku anak. Guru Kristen sebagai partner orang tua dalam mendidik, perlu menanamkan nilai-nilai moral yang sejalan dengan nilai-nilai Kristen yang luhur. Upaya yang dapat dilakukan untuk menanamkan nilai -nilai moral sebagai bentuk upaya pereventif pencegahan degradasi moral anak adalah dengan menciptakan komunitas moral di kelas.

\section{DAFTAR PUSTAKA}

Archambault, R. (2013). John Dewey and Education Outdoors. In John Dewey and Education Outdoors. https://doi.org/10.1007/978-946209-215-0

Bergant, D. C., \& Karris, R. J. (2002). Tafsir Alkitab Perjanjian Baru. Yogyakarta: Kanisius. 
Cully, I. V. (1995). Dinamika Pendidikan Kristen. Jakarta: BPK Gunung Mulia.

Dirhantoro, T. (2019). (2019 Mei 2). Retrieved May 2, 2019, from Alinea.id. website: https://www.alinea.id/nasional/korbanperundungan-terhadap-anak-didominasi-siswa-sd-b1XfQ9j4R

Durkheim, E. (1973). Moral Education. New York: The Free Press.

Fadhil, H. (2019). 2019 April. Retrieved April 11, 2019, from Detik News website: https://news.detik.com/berita/d-4506079/berawal-dari-bullydi-medsos-begini-kronologi-kasus-audrey

Haryanto. (2017). Haryanto. Retrieved May 4, 2017, from Harian Jogja website: http://www.harianjogja.com/baca/2017/04/05/pencabulanwonogiri-duh-bocah-kelas-vi-diduga-cabuli-teman-sesama-jenisnya807594

Huraerah, A. (2006). Kekerasan terhadap Anak. Bandung: Nuansa.

KBBI. (2016). KBBI - Kamus Besar Bahasa Indonesia. In Kbbi.Kemdikbud.Go.ld (3rd ed.). Jakarta: Balai Pustaka.

Kohlberg, L. (1995). Tahap-tahap Perkembangan Moral. Yogyakarta: Kanisius.

Lickona, T. (2014). Pendidikan Karakter: Panduan Lengkap Mendidik Siswa Menjadi Pintar dan Baik. Bandung: Nusa Media.

Moleong, L. J. (2010). Metodologi Penelitian Kualitatif (Revisi). Bandung: PT Remaja Rosdakarya.

Palupi, N. B. R. (2017). TribunJateng.com. Retrieved April 21, 2019, from TribunJateng.com website: http://jateng.tribunnews.com/2017/09/21/ begini-kronologi-tarung-ala-gladiator-yang-tewaskan-hilarius-hinggapelaku-tertangkap

Piaget, J. (1989). The Moral Judgment Dicipline. California: Caddo Gap Press.

Prasetyo, H., \& Listyandari, R. (2014). Virus-virus Perusak Kepribadian Anak: Membangun Mental Anak Sejak Usia Dini. Jakarta: Gramedia Pustaka Utama.

Rachels, J. (2003). Filsafat Moral. Yogyakarta: Kanisius.

Rahts, L., M, H., \& Simon, S. (1987). Values and Teaching. Columbus $\mathrm{OH}$ : Charles E. Merrill. 
Riska, A. (2012). Perilaku Manusia: Kajian Teoritis Munculnya Perilaku Manusia dari Alur Pikiran dan Perasaan. Yogyakarta: Kanisius.

UU RI. Undang-undang RI No. 2 Tahun 2002 tentang Perlindungan Anak. , (2002). 